\title{
On Paths of Imagination. Pico's Way towards Understanding Man
}

DOI: http://dx.doi.org/10.12775/RF.2015.012

It is not always easy to make deliberate decisions that are important from the point of view of a successful life. Choosing philosophy to be one's guide on the winding paths of life's choices may be quite helpful. This was the choice of the young man whose experiences and decisions I discuss in this article. It was quite early on in his life when Gianfrancesco Pico della Mirandola ${ }^{1}$ started dealing with philosophical thought and especially that which refers to man, his abilities, weaknesses, and the world around him. While becoming a lover of wisdom, he tried to understand everything that life brought to him with the help of knowledge. However, life was not always kind to him. In this article I refer to a certain series of events, a particular moment of his life, which is crucial for the reader to gain the right understanding of the origins of his work De Imaginatione. ${ }^{2}$ In this work, he makes use of the philosophical tools that are available to him to solve his most pressing personal

1 Gianfrancesco Pico della Mirandola (1469-1533), an Italian philosopher, a student of his well-known uncle Giovanni Pico, a humanist and polyhistorian, interested in philosophy and theology, an astronomer, a philologist, a mathematician, an orator and a poet. For a detailed biography of Gianfrancesco Pico, see: G. B. Richards, Gianfrancesco Pico della Mirandola, Cornel University Library, typewritten, press no. T 1915 R 515. For details of the life and philosophy of his known uncle see: e.g. B. Kieszkowski, "Giovanni Pico della Mirandola". In "Przegląd filozoficzny" 33, 1-4 (1930).

2 Pico's concept of imagination was the subject of my article titled Remarks on Imagination. Notes on the Margin of De Imaginatione by Gianfrancesco Pico della Mirandola (1469-1533). In Вісник НАУ. Серія: Філософія. Культурологія 20, 2 (2014). 
problems. One of them is the eponymous imagination, the influence of which cannot be overestimated. Pico's writing coincides with a time of new interpretations of the philosophical legacy of the antiquity, which served as a source of inspiration for Pico. Thus, in this article I refer to some ancient sources featuring the concept of imagination, as those had the strongest influence on the final shape of Gianfrancesco Pico's views. These were Aristotle's considerations included in his De Anima.

While he was writing his work Pico was only 29 years old. He was married and had a seven-year-old child. Some initial hardships of fatherhood were already behind him but some-prosaic aspects of life were increasingly creeping into the lives of the young couple. Pico had some life experience backed by a certain amount of social familiarity and refinement, which resulted from his education as a prince. At the same time, because of the acquaintances of his uncle Giovanni ${ }^{3}$, who was six years older, Pico took an active part in the intellectual life of the Italian humanists from an early age and even corresponded with many of them. ${ }^{4}$ All this leads us to believe that he was not a reckless stripling, but a man of clear and determined interests. He did not yet have, however, a critical approach to the philosophical views that he learned about, and like his contemporaries, including his uncle, he upheld a great reverence to ancient thought. His early thoughts lack the scepticism which is characteristic of his later works which can be easily seen in the treatise On the Imagination. The text was written in 1499 in quite difficult circumstances as Pico's father died at the time. Soon after that, his younger brothers Ludovico and Federico, with the help of their mother began to apply for the rights to titles and estates, which had been inherited by the philosopher. Finally, after great effort, they managed to capture Pico on $6^{\text {th }}$ August 1502 and expelled him from his land. The full title of the work: A Book on the Imagination Written by Gianfrancesco Pico, Prince of Mirandola and Lord of Concordia was still true at the time. He could have assumed then that he would face similar problems throughout almost all of his adult life. They ended only with his death at the hands of his nephew Galeotti in 1533.

While writing about the great variety of Pico's talents and interests, Harry Caplan wonders how he could ever have been such a prolific

3 Unfortunately, his uncle died in 1494 and so the young Pico lost his mentor at the age of 24 .

${ }^{4}$ It is worth mentioning the names of Battista Guarini, or Marsilio Ficino among his uncle's friends. Pico also corresponded with his peers, e.g. Ariosto Bembo, Calcagnini, Giraldi. In later times he was in close contact with Savonarola. See: Caplan H. Introduction. In Pico della Mirandola Gianfrancesco. On the Imagination. The Latin Text with an Introduction, an English Translation, and Notes by Harry Caplan, Cornell Studies in English, XVI (1930), p. 1. 
thinker, since he faced so many adversities during his life. ${ }^{5}$ The Italian thinker is an author of a great number of works, which relate to almost every contemporary field of knowledge. We know, however, that he was troubled with insecurity and that he longed for his native estates and peaceful life. He already expresses this thought in a dedication to the Emperor Maximilian, and shows anxiety whether his imagination did not beguile him: "it might happen to me once that I will obtain (what I pray for) a little peace and quiet, (...) In the clash of arms, riots raging in Italy, and efforts to expel the enemies of my estate, I found some time to save these thoughts on imagination, which, unless my own imaginations deceives me, will not be worthless to readers, if there are any of them."

Pico must not only have been disappointed with the conduct of his closest family but also anxious about his own life, as well as the lives of his wife and child. All this was accompanied by a sense of betrayal and lack of understanding of the behaviour of his brothers and mother. As a philosopher, he certainly wanted to understand their motives. That is why he reached for the most widespread tool at the time, which was the Stagirite's philosophy. He found the answers in his concept of imagination. However, he had to develop it a bit, as well as modify and restrict it at the same time. His theory is grounded in everyday experience. The functions of imagination that he outnumbers and its role in our lives seem to be confirmed by facts. The philosopher did not just want to sim-

5 See the following passage: “...he composed something in almost every field of intellectual interest. How such industry was possible, and how such excellence was achieved, it is difficult to understand when one considers the incessant and violent warfare within his family for the possession of Concordia and Mirandola, a struggle that engaged his time and energy from 1499 until his assassination. What with attack, defense, negotiations, victory, defeat, exile, bloodshed, almost constant insecurity, we need not to be astonished at his repeated complaint over the tumultuous life he led. And his lament is for his interrupted studies." (Caplan H. Introduction, op. cit., p. 1).

6 Pico della Mirandola Gianfrancesco, On the Imagination. The Latin Text with an Introduction, an English Translation, and Notes by Harry Caplan, Cornell Studies in English, XVI (1930), p. $20 \mathrm{ff}$. Caplan provided the information in a footnote in which he explained the contemporary situation of the prince: "From 1499 to 1501, Gianfrancesco Pico was at war with Anton Maria, his father's youngest brother, for the possession of Concordia; and in the very year of the writing of this tractate he was disputing for the title of Mirandola with his own younger brothers Lodovico and Federico. In fact, a month before the date which he affixed to the Dedication, he had sent an ambassador to Ferrara to attempt a compromise with his brothers. Maximilian never very actively assisted Ginafrancesco in his family disputes; and his moral support was wavering and inconsistent. See: G. B. Richards, Gianfrancesco Pico della Mirandola, chap. 3. Miss Richards, p. 105, writes: "As early as 1490 the political degeneration of Italy had begun, and no prince in the land suffered more from military campaigns than did Pico." (Pico della Mirandola Gianfrancesco. On the Imagination, op. cit., p. 20, footnote 2.) 
ply understand the situation. He sought some remedies to all the evils resulting from the power of imagination; he wanted to point out a remedy that would cure the disease that was eating his family away. He found that in controlling imagination, in indicating the right way for it to go, directing it and harnessing how it acts was a possible remedy for this disease. After all, he did not deny all of its consequences as it may always become useful through education and act in a better way than any total ban. Pico would have had far fewer problems, had his brothers received a better education, had they not let themselves be deceived by their own imagination and be overcome by their lust for power and honour.

Pico saw the final solution to all problems, not just his own, in the light of faith, the Scriptures, and in the word of Christ. We do not know, however, how such a clue should be understood. It was perhaps all too obvious for Pico. We know that revelation was the highest criterion of truthfulness for him and it escaped the edge of criticism resulting from some sceptical views. Due to revelation, man could protect themselves against the negative influences of imagination, see the appropriate value of things and deeds, and control improper passions and lewd thoughts.

Pico solved his problem with the help of his concept of imagination, which combines epistemological and psychological analyses with ethical ones. He was able to fully understand the situation in which he found himself as well as the motives of the people who were closest to him and people in general. Theoretical considerations including the practical postulates derived from them did not work out in reality. Although Pico understood the mechanism of human motives, it changed nothing for his relatives. The conflict with his brothers was even intensified when, among other things, they imprisoned Pico's son. It turned out that people who were blinded, dominated and manipulated by their own imagination could not be simply taken out of that state. It was insufficient to explain their situation to them, show what guided them in their lives, or tell them that they harmed others by succumbing to their own imagination. Pico did not find any solution to this problem. It seems that he only satisfied his own curiosity, which was certainly fuelled by imagination.

Philosophy became a way for Pico to understand concrete situations. He did not take his decision intentionally, as he was not a mature thinker but only a young humanist, who was at the very beginning of his intellectual development. Pico did not yet have rich life experience and a good knowledge of human nature, which results from having had a full and rich existence. Thus, it is even more difficult to expect him to have been acquainted with theoretical concepts which explained the motives of human actions. Aristotle's work which was very popular at the time, discussed by a vast majority of the Italian humanists, presumably Pico's uncle too, and widely studied at universities must have 
come to Pico's mind to use as a useful tool of its own accord. Therefore, in order to properly understand the origins of Pico's views on imagination, an awareness of his contemporary thinkers views regarding the correct way to understand philosophical thought from eight hundred years ago needs to be studied. In addition, a reconstruction of the Stagirite's concept of imagination will be required. However, it should be noted immediately that Pico does not refer to all aspects of the roles and function that the imagination could play in human life as were distinguished by the great Greek philosopher. ${ }^{7}$ Sole theoretical considerations were not Pico's aim. The selectiveness of his analyses and borrowings shows that his focus was different and concentrated on searching for explanations of the motives of actions undertaken by his enemies as well as practical hints which would help to prevent them in the future.

Thinkers in the $15^{\text {th }}$ century turned to the past as they wanted to rediscover the value of the ancient works, which was lost in the past and distorted or damaged in the Middle Ages due to either carelessness or a lack of care. They attempted to understand again the contents of the ancient philosophical treatises in order to include them in the scope of useful knowledge, which, in turn, supports all mankind. As easy as it seems for one to guess, it was impossible for the entirety of Aristotle's works to survive in the context of the new discoveries of the time. The old maps lost their validity, the old descriptions of the world turned out to be incomplete, and the old conceptions of it were totally irrelevant to the new visions and aims set by man. However, while Aristotle's physics were slowly becoming obsolete (they were no longer useful in determining the angle in which cannon was supposed to be set in order to make its ammunition fly the furthest), his metaphysical considerations survived. It became a point of consideration, together with their reception, as to whether the translations of the Stagirite's works were accurate and the medieval copyists, who were rewriting scroll af-

7 For detailed data on the development of Pico's relation to the views of Aristotle see: Ch. B. Schmitt, Gianfrancesco Pico della Mirandola (1469-1533) and His Critique of Aristotle, The Hague: M. Nijhoff, 1967. Schmitt stresses there Pico's main objections to Aristotle, i.e. that the Greek philosopher assigns too much role to the senses in cognitive acts. For this reason, Aristotle's considerations remain at the level of some probable digressions, without the possibility of achieving a satisfactory criterion of validity. Schmitt adds, however, that this part of the criticism stems from the simple fact of assigning the role of an empiricist attitude to Aristotle in a greater extent than it is present in his writings. And since Pico read the Greek editions of works of Sextus Empiricus in great extent at that time, he was infected with his skepticism, and so he tried to eliminate the often dogmatic thought of the Stagirite even more eagerly. Sextus Empiricus's works also contributed to the discretion of a view by Pico, according to which an observable disagreement among philosophers on even the simplest of issues, leads inevitably to the impossibility of understanding and reconciling their concepts. 
ter scroll, were trustworthy. In parallel to this, the works of the Greek philosopher were being discovered in the versions kept in the Arabic libraries, i.e. versions that had not been distorted by scribes with their interjections or corrections. A substantial part of the Stagirite's works was preserved for future generations by Islamic philosophers. Thanks to their tireless dedication, philosophy in general had been gaining a greater reputation since the $9^{\text {th }}$ century. By the $12^{\text {th }}$ century his Prior Analytics, Topics, and On Sophistical Refutations were already known. There were also parts of his Categories (Book I), On the Soul, Physics, and Metaphysics available. ${ }^{8}$ Aristotle's works were not the only ones that reappeared at the centre of interest at the time. Additionally, all available ancient knowledge, was rediscovered by the fifteenth century humanists at this time. Eugenio Garin, a contemporary Italian historian of philosophy, wrote the following words about its reconstruction: "It also makes no difference that the ancient knowledge includes falsehood and hoaxes, and that the new 'library' is full of Apocrypha, that the recalled antiquity contains so much of the medieval thinking, and that so many myths are continually interwoven in the history. In the great myth of 'rebirth' the Apocrypha will gain authenticity, the myths will become the history and they will touch it. That what is really important, however, if one wants to capture the distinctive features and the innovative character of the era, turns attention to the fact that the other return of 'the ancients' is made according to some various rhythms of time, that it possesses certain forms, internal tensions, and that it has some deep and extensive consequences. It is important, as it needs to be underlined, to differentiate and use periodization, in order to realize that we do not deal with a chaotic and undiversified mass of randomly accumulated works, but with a clearly defined dialogue." ${ }^{\prime 9}$

The process of the rediscovery of ancient philosophy was a common programme for the Italian humanists. and it resulted in many disputes among them. It would be difficult to expect every thinker of the time to be a follower of both Plato and Aristotle. A belief in the possibility of reconciling these two philosophical doctrines together with an accompanying conviction that they can be enclosed in a synthesis with Christian thought seems to be quite naive. Such a position was not uncom-

8 Young Pico might have got acquainted with the Latin translations of Averroes' Arabic version of Poetics. Cp.: M. A. R Habib, A History of Literary Criticism and Theory: From Plato to the Present, Wiley-Blackwell, 2005, p. 60.

9 E. Garin, Powrót filozofów starożytnych, transl. A. Dutka. In L. Szczucki (ed.), Renesans i reformacja. Studia z historii filozofii $i$ idei, Warszawa: PAN IFiS, 1993, Vol. 2, p. $10 \mathrm{ff}$. For a detailed description of the influence of source texts on the $15^{\text {th }}$ century humanists see: S. Świeżawski, Dzieje filozofii europejskiej XV wieku, Warszawa: Akademia Teologii Papieskiej, 1974, Vol. 1, especially: part 1: Uwarunkowania życia umysłowego w XV wieku, Chapter 2. Zachód a wschód. 
mon however, which is perfectly illustrated using Pico's uncle, Giovanni as an example. Although he played a significant role in the process of the philosophical education of his nephew, neither Italian managed to reach a compromise in the following issue:

"Giovanni and Gianfrancesco Pico, who maximally detailed two parallel positions on "consent" and "discord" of the philosophers, illuminate the situation in an almost paradoxical way. Giovanni Pico tends to show "compliance" or harmony between different positions through the subject of "comparatio", i.e. comparison. In Examen vanitatis doctrinae Gentium Gianfrancesco Pico states the impotence of reason, starting from Sextus Empiricus and accentuating the differences between philosophers and radical contradictions between them. Both philosophers find it necessary to compare the philosophers of the past among themselves and with the contemporary ones. (...) For Giovanni Pico the light of truth is the climax of reason which is achievable in a meeting of all that is positive in any research effort. On the contrary, for his nephew Gianfrancesco, the ardent follower of Savonarola, the comparison reveals an incurable conflict between philosophers and overwhelming weakness of human reason in the face of the solution proposed by religion. For both of them however, the criticism of all the efforts and all the positions, as well as their exact and most authentic reconstruction is both preliminary and indispensable."10

However, the impertinent attitude of Gianfrancesco Pico, the contemptuous tone in his statements regarding ancient philosophy ${ }^{11}$, and a complete lack of understanding of the attempts to reconcile its works

10 E. Garin, Powrót filozofów starożytnych, op. cit., p. 59ff. Gianfrancesco opposed his uncle's concept of a "consent", and expressed it in the treatise, in which "he refuted the idea of all the ancient schools of philosophy, in particular Aristotle's doctrine." (Garin E. Powrót filozofów starożytnych, op. cit., p. 90). Analyzing the philosophical attitude of the young Pico in another work, Garin writes that: "Philosophy is discursive as a comprehensive process; it attempts to reach the truth by natural reason. If philosophy could fulfill its tasks, it would almost fully exhaust the issues of religion. If the theory of the pia philosophia - the theory of some basic compliance of views of ancient and Christian philosophers was true, the most important teachings of Christianity or its deepest value would blur. (...) There is no agreement among philosophers. Reason alone is not sufficient. There is a super rational certainty of revelation over the intricate fabric of lies of reason, the contradictions of intellect, and the absolute insufficiency of human inquiry. (...) Gianfrancesco shows the Classical Antiquity, which was praised by the majority of the modern as a model of excellence, as the craziest contradiction of all. What is over the crisis of reason, above humanity, whose absurd efforts resulted in a complete failure, is dominated by the word of Christ. " (Garin E., Filozofia odrodzenia we Włoszech, transl. K. Żaboklicki, Warszawa: PWN, 1969, p. $182 \mathrm{ff}$.

11 When referring to the problem of copying classical authors in the polemics with Piet Bembo, Pico presents a negative point of view: aemulator veterum verius quam imitator. Cf. W. Tatarkiewicz, Dzieje sześciu pojęć, Warszawa: PWN, 1976, p. 322. 
with Christian thought are not uncharacteristic of his young age. He was only 29 years old at the time of writing De Imaginatione, and, like his uncle, he was still under the strong influence of the spirit of the times, which was becoming influenced by Aristotle's thought. How could he even try to break out of the prevailing rigor in science in such circumstances, out of the proper writing style, reach for the right works of the old masters, and, finally, out of the adoption of correct views? He was too young, too inexperienced, and, what is more, he was unknown in the wider circles of the recipients of philosophical works. It is not surprising then, that his early writing is so different from the rest of his work ${ }^{12}$, and that the views it contains seem to be rather unoriginal, eclectic, and not fully thought out. In his deliberations, Pico simply followed Aristotle's thought, i.e. the guide of his times.

In order to understand Pico's concept of imagination, it is vital to consider both Aristotle's On the Soul, which is devoted to the issues of the soul and cognitive powers as well as Poetics, which deals mainly with the subject of tragedy and archaic concepts of mimesis and catharsis, which are related to it. A reference to these two works will enable us to reconstruct Aristotle's views on the way imagination functioned, both in the processes of cognition, as well as in a widely understood artistic work.

The Greek $\varphi \alpha v \tau \alpha \dot{\sigma} \sigma \alpha$ mostly means appearing or revealing itself. At the same time the concept conceals such meanings as that of an impression, an idea or an imagination, but also a mirror reflection, an appearance and a notion. ${ }^{13}$ This range of meanings can point to the fundamental role of imagination, which allows images to appear in the mind. This applies both to cognitive acts which have their source in sense impressions and the acts of imagination which are performed on previously obtained images. On the one hand there are appearances of things in the mind that are not currently perceived by us. On the other, there are some operations on the previously obtained perceptual data, the causes

12 See the following commentary of Charles B. Schmitt, a scholar of the history of Italian philosophy: De Imaginatione, published in 1501, is a short work that turns out to be far more open to the positive aspects of philosophical studies than those which appear later on. It can be noticed without doubt that from all the writings which have survived, only De Imaginatione puts the traditional philosophy in a more or less favorable light, and is the only one that has been devoted to the development and clarification of the classical philosophical problem." (C. B. Schmitt, Gianfrancesco Pico. Leben und Werk. In Pico della Mirandola Gianfrancesco, Über die Vorstellung = De Imaginatione. Lateinisch-deutsche Ausgabe; mit einer Einleitung von Charles B. Schmitt, Katherine Park; herausgegeben von Eckhard Kessler, München: Fink, 1997, pp. 13-14).

13 Cf. K. Narecki, Słownik terminów Arystotelesowych. In Arystoteles, Dzieła wszystkie, Warszawa: PWN, 1994, Vol. 7, p. 122. 
of which, i.e. objects are not currently recognized by us. In the first case we get to know the external world, in the second one, there is a transformation of the inner world (i.e. the world of ideas).

What is most important, however, is that the act of the first type allows the occurrence of the other. Imagination would have nothing to work on, had it not once acquired empirical data. Therefore, the senses are like a gateway through which information about the world comes. According to the model of cognitive powers that was proposed by the Stagirite, any cognition begins with a qualitative change in the sense organs. This change is possible due to motion, and to be more specific, due to setting the presently transparent medium (i.e. air) to motion. ${ }^{14}$ Things move our sense organs mechanically, almost hitting them, or impressing on them. That results in certain impressions, but not the images of things. The latter may arise due to the common sense (kolvi), which guarantees the unity of apperception. The internal sense, which was postulated by Aristotle, allows us to unite certain impressions of different external senses, which capture the kind of data that is only relevant to them. The task of the internal sense is to connect them together and create an appearance or an image of a thing. Interestingly, that ability is also a possibility of distinguishing between things and evaluating them. We can extract certain qualities of an object from the whole presentation with its help, like e.g. colour, shape, smell, etc. We can also compare, collate, and evaluate them.

In Aristotle's early observations on imagination it is characterized as a power which is "(...) not the same kind of thinking as supposal is clear. For the former is up to us when we wish (for it is possible to produce something before our eyes, as those do who set things out in mnemonic systems and form images of them); but believing is not up to us, for it must be either true or false."15

The above quotation turns our attention to the following two things. Firstly, imagination does not come into existence without perception, secondly, its proper object, i.e. an image depends on our own power. On the one hand it means that imagination is passive, as it is dependent on the perceptive material given by senses and the common sense. On the other hand, it is active, as it allows us to make changes in this material. This distinction enables us to differentiate between a perception and an image. As far as the former is independent of us, as it completely relies on the receptivity of senses, the latter is based on the ac-

14 Cf. Aristotle, De Anima. Books II and III (with passages from Book I), translated with Introduction and Notes by D. W. Hamlyn, with a Report on Recent Work and a Revised Bibliography by Ch. Shields, New York: Oxford University Press, 2002, Book II, Chapter 7, p. 26ff.

15 Aristotle, De Anima, op. cit., p. 53. 
tivities of imagination itself. Images however, are not always subject to the guidance of will. For example, only in a few of our dreams do we have a vague sense of deciding about what appears and which scenes take place in them. A similar situation may occur when our stimulated imagination presents images that it, so to speak, chooses itself, but in fact they are related to one another in a different way. It happens in such situations, for example, when we feel fear or dread, when reason, dimmed by current sensations does not control the situation fully. Not everything is clear and understandable to it and imagination suggests images that cause an even greater sense of threat.

If the sources of images are to be sought in the sense impressions, they should, like the impressions themselves, be explainable with the help of the concept of motion. And indeed, this is the way Aristotle deals with the issue:

"(...) Imagination is thought to be a kind of movement and not to occur apart form sense-perception but only in things which perceive and with respect to those things of which there is perception, since too it is possible for movement to occur as the result of the activity of perception, and this must be like the perception - this movement cannot exist apart form sense-perception or in things which do not perceive; and in respect of it, it is possible for its possessor to do and be affected by many things, and it may be both true and false."16

Such an approach to imagination leads to a definition of the power of imagination as that of a movement caused by actual perceptions. It is imagination, which enables the appearance of images and conditions any operations on them ${ }^{17}$. This term, however, is incomplete because it does not include memory, without which we would be condemned to the constant experiencing of actual sensations, with no possibility of comparing images, learning, eliminating mistakes, and even imagining. It seems that they are stored together with the concepts which are associated with them through convention and experience. It is enough to renounce any word to order make imagination present, as if on cue, a number of corresponding images, and for its most important designations to appear. Thus, memory is a kind of reservoir of images, a storehouse in which these images are collected and bear tags that are un-

16 Ibidem, p. 55.

17 In order for our perceptions to be clear, i.e. in order for our images (eidolon) of things to be able to boast about some resemblance with them, it is necessary that certain conditions come into being. And although we can recognize items of equipment in a room in the darkness, it happens mainly because of our prior familiarity with them in some more favorable circumstances. Aristotle draws our attention to the fact that it is light that enables us to see things, and vision is the most important among our senses. Due to that the imagination, as it is suggested by Aristotle, re-

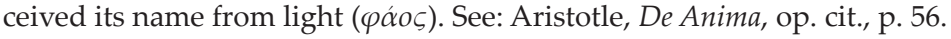


known to us, but which in most cases allow us to find and bring the ones we need.

This relationship of notions and images ${ }^{18}$ is possible due to the ability of memory to store images. According to the Stagirite "(...) for each sense-organ is receptive of the object of perception without its matter. That is why perceptions and imaginings remain in the sense-organs even when the objects of perception are gone." ${ }^{19}$ And this means that an object of imagination is not really an object that exists, which is a combination of the form and matter, but only its form. How could matter be present in the soul? Imagination operates only on what represents the matter, i.e. on an appearance, an image, or a picture. Therefore, when there is a perception, i.e. when the movement causes a change in our sensory organs, the latter communicate their data to the common sense, which unites the data of every sense on that basis and reproduces that particular thing in the same way. The resulting image is only a form of the real object. All the functions of imagination mentioned before manifest themselves on the level of the sensitive soul.

In contrast to the nutritive soul, which is oriented around human survival, i.e. giving birth, growth, and nutrition, and to the rational soul, which is focused on the intellectual understanding, the sensitive soul is responsible for the realm of sensations and images. It is thanks to the latter that an emotional reference to the object causing the image is possible. However, this type of soul appears only in the animal world, as a condition of its formation is, of course, the possession of senses that deliver impressions, which are the ones of pleasure and pain. The sensitive soul becomes a stage for feelings which arise from its activities. In describing their appearance, Aristotle points to the fact that " $(\ldots)$ when something is pleasant or painful, \{the soul\} pursues or avoid it, as it were asserting or denying it; and to feel pleasure or pain is to be active with the perceptive mean towards the good or bad as such." ${ }^{20}$ Experiences are therefore a reaction to the images created in the mind, which must correspond with the objects of some characteristics suitable for the excitation of certain feelings. Due to that, all animals with senses, including men, can recognize what gives them pleasure, and thus attracts them to it, and what causes a feeling of pain, and thus repels them.

On the one hand, that simple psychological model allows Aristotle to explain the way in which men as well as other animals orient themselves in the world, on the other, as we will see later on, to understand how art can affect human beings and how they can create it. Let us look

18 Notions and images are so tightly connected, according to the Stagirite that it is impossible to think about anything without considering images at the same time.

19 Aristotle, De Anima, op. cit., p. 48.

20 Ibidem, p. 63. 
at the issues connected with the second aspect of the way imagination functions, which is undertaken by Aristotle in his Poetics. Only a comparison of the contents of both works will enable us to fully understand his concept of imagination. We need to bear it in mind that Pico did not refer to the text of Poetics, which may mean that he either did not read it or for certain reasons considered its content unimportant. He did not take into account the Aristotelian concept of mimesis in his own description, which forces us to consider whether it is possible to think of it as a fully thought-out theory of imagination. With the ignorance of imitation, or more broadly the creative role of imagination in human life, Pico's views on the natures of that ability are limited and seem to refer to only a few spheres of human activity.

I mentioned earlier the possibility of recognition of objects which are devoid of the material root by sense organs and, consequently, also by using imagination. Thus, the qualitative change that takes place in our minds takes the form of an object, and the matter itself is left in its place in the outside world. With respect to the creative activity: roin $\sigma \iota \varsigma$, or more broadly $\tau \dot{\varepsilon} \chi v \eta$ that concept can be considered from two points of view. In one respect, the intention of the artist is the formal cause for a piece of work to come into existence. The purpose understood here as an idea of the product precedes its realization. An artist, who interacts with the object of his imagination, works on it and makes it more precise to reach the intended aim, i.e. causing certain feelings in a recipient. In another respect, the issue of forms of things solely coming into existence in the mind, taken from the perspective of a viewer, leads to some interesting conclusions. While analysing the process of reception of works of arts, we can emphasize following Starobinski that: "On the one hand, the image retains the ability to induce our passions, and cause resonance in the depths of our bodies, which is proper to reality. On the other hand, since the presented event is not real, the emotions it causes will be able to unload in a pure way (with a pure loss); that results in purification, catharsis. An idea of an image leads us to a notion of release through a discharge of feelings caused by illusion. It is also important to note that the presented fate, i.e. the one which is developed in the substance of the word and image, is a tamed fate". ${ }^{21}$

When considering the problems of Aristotle's Poetics, Starobinski notices that imagination is only a form of an object, and in the same way it is freed from its material burden. Although Poetics includes an analysis of tragedy we can extend the remarks to the entire artistic creation. Therefore, we can say that when associating with a work of art, we experience events in an imitative manner, which is referred to as a pure by

21 J. Starobiński, Wskazówki do historii pojęcia wyobraźni. In "Pamiętnik Literacki", transl. W. Kwiatkowski, LXIII, 4 (1972), p. 221. 
Starobinski. It should be understood as a kind of freedom from some unpleasant consequences of the materiality of life experience. That is why watching the scene of Prometheus whose ever re-growing liver is being eaten by an eagle certainly does not evoke a feeling of pain in a viewer. This view itself however, will be suggestive enough, so that one could imagine experiences of a tortured person. The illusion of the presentation allows, therefore, experiencing the fate of the hero of the tragedy, and remaining aware of the independence of our lives from the tangled events portrayed in a piece of art. As a result, the viewer is able to abstract from the vicissitudes that have been witnessed and experience the feeling of pity and fear, and experience catharsis in accordance with the Aristotelian definition of tragedy. The sole fact of the spread of feelings, meant as an element of the effect of the work of art, which was taken into consideration in the process of creating art by the artist is possible because the world depicted in it is not a simple copy of the current events. We can certainly say that all the events are real, as the artist creates them. However, we have something different in mind here. The created world is not totally independent from the real one. The concept of mimesis, which describes the relationship between the world depicted in a work of art and the real world, derived from the triune chorea, is of quite a clear and precise meaning. Plato narrowed it to the concept of a copy, and he consequently found that the performing arts are the shadows of shadows with no value. They can even make it impossible to know the truth and they stimulate passions and destroy the internal harmony of the soul at the same time.

Meanwhile, it is as if Aristotle came back to an archaic way of understanding the term of mimesis i.e. to the one of mimetic gestures of a mime or a priest. The term plays an important role in The Poetics. Mimesis enables some mimetic presentation of a serious activity. ${ }^{22}$ This imitation does not simply mean the reconstruction or repetition of the thing that was earlier conceived in sensory experience, it is rather a certain concentration of perceptions. Mimesis means correcting the natural world and human relations, and ordering them in comprehensive sets of events. Having taken into consideration the ambiguity of the notion of a form as Aristo-

22 See Aristotle's definition of tragedy: "Tragedy, then, is mimesis of an action which is elevated [emphasis added - K.W.], complete, and of magnitude; in language embellished by distinct forms in its sections; employing the mode of enactment, not narrative; and through pity and fear accomplishing the catharsis of such emotions." In: Aristotle, The Poetics. Ed. and transl. by Stephen Halliwell, Chapter VI. In Aristotle. The Poetics; [edited and translated by Stephen Halliwell]. Longinus. On the sublime; [translated by W. H. Fyfe; revised by Donald Russell]. Demetrius. On style; [edited and translated by Doreen C. Innes based on W. Rhys Roberts]. Loeb Classical Library; 199, Loeb Classical Library. Aristotle; 23, Cambridge Massachusetts, London, England: Harvard University Press, 2007, pp. 47-48. 
tle presents it, it must be added that it can be considered as the essence. Then, it will be justified to say that tragedy presents the essence of events apart from any accidental elements, for example human fate, or an event that could happen to everybody, but which should be exactly the one, if we want to cause certain impressions on a viewer. Due to this reason, the difference between history and tragedy is that the former shows the events in such a way as they happened in reality, while the latter shows a vision of events, which could take place but not in a particular life of a human being. This means that an appearance of an image consists in an accumulation of some particular and intentionally selected events. That is why Aristotle says that tragic art is more philosophical than history, as it functions on a different level of generality, providing, however, that the presented world is more or less probable. Otherwise, it would be completely incomprehensible to the viewer.

Summing up, it needs to be underlined that the role of imagination in human lives starts with the first sense data acquired by us, on which it operates. It serves our cognition, consideration, learning, dreaming, planning, experiencing works of art, and all our other activities throughout our life. Pico was well aware of the variety of ways in which imagination could be used. However, it was not his aim to present all the aspects of its functioning in human life. His selectiveness resulted in an attempt to show it in its several basic manifestations rather than in a mature conception.

In his attempt to present the power of imagination and its role in human life, Pico does not limit himself to showing it only as a cognitive power or a confidante of senses. Of course, he is aware of its mediating role between the lower and the upper cognitive powers, i.e. senses and intellect. He notices however, that it does not always play its role in the right way. Obviously, he sometimes writes about imagination as a power which beguiles and deceives man. Due to the fact that it has got much in common with senses, the way it functions results in dire consequences, cognitive mistakes, and misunderstandings in relations with other people. Similarly to senses it operates on images, particular presentations, which they provide it with. We know that such an image can be deceptive, as it is proved by illusions, afterimages, or hallucinations. It can also be a source of strong emotions. That, what it shares with senses, i.e. operation on the sense data, makes it imperfect and prone to mistakes. However, what makes it resemble the higher power, intellect, causes that it finally exceeds the limits of senses. It can abstract from a particular representation either to produce an image from a manifold of particular sensory experiences or to connect and compact them together in such a way that they present something very different, which is even valuable in an aesthetic sense. Imagination abstracts from a concrete, singular sensory experience and enables learning (abstracting, 
hypotheses, syntheses, and even deduction), predicting the probability of events as well as their causes. Finally, it helps man to get to know, not only, himself but others too.

The last of the abilities mentioned above was particularly interesting for Pico. He wanted to know how imagination affects the way we perceive other people, their behaviour, habits, and discover their characters. In accordance with one of the dominating views at the time, he considered imagination to be a power partly determined by the body, precisely by bodily fluids. ${ }^{23}$ Imagination was supposed to change the content, which was passed to the intellect, depending on which bodily fluid gained advantage: blood, phlegm, red or black bile. The change did not refer to the way it functioned but to what it emphasized or hid in a perception or an imagination. According to Pico this was where ailments or imperfections of imagination resulted from. Obviously, the perceived objects themselves could have been their sources as well. It is sufficient for our observations to become superficial and inaccurate when they are subject to frequent and quick changes. It is enough for a quarrel between lovers to be seen in a different way when it is taken out of context.

Pico's intention is not only to claim that there are certain reasons for which imagination is mistaken. On the contrary, he insists that he can find a remedy for that. The process, however, requires the support of reason, the light of which will illuminate the way on which imagination will be

${ }^{23}$ See the following passage: "It is the testimony of philosophers and medical men that one's imagination is determined by the relative supply of blood, phlegm, red bile, or black bile. Thus, in correspondence with the diversity of humours, one's imagination is stimulated to diverse images: cheerful, dull, grim, sad. Influenced by these humours in the act of cognizing, the spiritual eye of the soul, the intellect, changes and is deceived, just as the bodily eye experiences illusions through tined, parti-coloured lenses. The spiritual eye, joined to the body, makes use of images to contemplate truth, as the eye of dull visions uses glass lenses to gaze at a sensible object; and it is deceived exactly as is the bodily eye itself." (Pico della Mirandola Gianfrancesco. On the Imagination, op. cit., p. $35 \mathrm{ff})$. A similar remark is included in Szumowski's History of medicine: "Innate warmth is a important factor of life. It has its source in the heart and it digests sustenance, separating between its useful and useless parts. Four basic fluids or juices (Latin: humores) play an important part in the human body. These are: blood, mucus, yellow and black bail. (...) The science of the four fluids is the basis of whole physiology and pathology of Hippocrates. When they are in order, there is not too much or too little of any of them, and they are duly mixed (Greek: eukrasia) the man is healthy. When they are badly mixed (Greek: dyskrasia), there is too much or too little of one, then the man is unhealthy. That is why Hippocrates pathology, which is based on the science of fluids, is a humoral pathology (Latin: humor - fluid). Unfavourable state of juices arises as a result of different reasosn, which are thoroughly discussed by Hippocrates inluding the influence of climate, season, weather, living conditions, age, lifestyle, food, water, and attiring." (W. Szumowski, Historia medycyny, Warszawa: Państwowy Zakład Wydawnictw Lekarskich, 1961, p. 50 ff). 
able to stride. It will help us in noticing the reasons for mistakes, understanding their sources so that we will be able to oppose them at the same time $^{24}$. According to Pico it was enough to change the subject of our interest from the one, which attracts us in an unhealthy (i.e. indecent) way to something more worthy of attention. When we are distracted and our imagination quickly runs one after another of its subsequent objects, we should focus on an individual perception. That simple method can also be applied to our emotional states, which means that when we are sad we should focus on something that would cheer us up, while when we are too delighted (which Pico also takes into account) - on something that would bring us back to harmony, in particular something that is religious. Such objects of interest, which are connected with religion, faith, proper and estimable life, become, for Pico, the last support for reason in its fight with passionate imagination. Reason alone, in his opinion, is not sufficient there. We need true faith and certainty, which results from it and allows us to make the right choices. Armed in such a way we can set imagination to our purposes and bring others as well as ourselves to the right path and knowledge of the difference between right and wrong.

The parts of De Imaginatione in which Pico tries to sketch the right path of life seem to be the least precise. They fully show the naivety if not infantility of his ideas, which resulted from his young age and lack of experience. He is not able to provide an answer to the question about specific indications or maxims, which are to be followed in life. Certainly, that is why he finds it easier to regard the Scriptures as a guide and the Lives of the Saints as role models than to recommend any specific behaviour. The saints provide an example and quoting their fates is supposed to heal imagination. What is interesting is that it is still a sensory impact and not the one that would remove sensuality with its stimuli from life, as one might expect. Pico is aware of this fact. He knows that it is possible to show a life of renunciation and sacrifice for the sake of higher goals. He also knows that one's self-control can provide a life ideal which should be aimed at in the name of happiness. He is also well aware that the pictures of hellfire can affect human imagination with equal or even stronger force and make an appropriate impression on man. However, a few questions arise here. Is such a method valuable at all? Does it lead to the desired goal? For some people certainly yes, but is this really what the point is here? Actually, it may be better to follow the recommendation of studying the Scriptures and the Lives of the Saints. Yet, can a practice like that, even if it is combined with the light

24 Obviously, it should be added here that reason was supposed to enable the right understanding of human behaviour, motives of actions, and better knowledge of human nature in general. 
of the Christian faith, help Pico in solving the problems which he found most absorbing?

"Nor is it hard to prove - we read in On the Imagination - that universal errors which occur as much in civil life as in the philosophic and Christian life, take their beginnings from the defect of the imagination. The peace of the State is disturbed by ambition, cruelty, wrath, avarice, and lust. But then the depraved imagination is the mother and nurse of ambition, and thinks it a fine thing to outstrip all others, albeit without regard for the virtue or nobility whereby those may shine whom the man fired by ruinous ambition busies himself to surpass in honors. Cruelty, wrath, and passion are born from and nourished by the imagination of an ostensible but deceptive good, which one who is carried away by perfervid sense and rash imagination to insults, wounds, and murders, thinks inherent in retaliation. What else excites the insatiable thirst for gold? What else kindles the ardor of lust? And what else, if not the deceitful imagination, brings to the fore the other vices (...)? Neglecting reason, she gives precedence to injustice, to savagery rather than to clemency, to avarice rather than generosity, to discord rather than to peace." 25

Can the light of faith deal with the great influence that imagination has on man? Can we control imagination with the help of rather naïve tricks such as diverting one's attention or changing the subject of interest? Even studying the Scriptures does not seem to be enough in that respect. How can one control the power which can move us in such a way that an imagined death of a person close to us strike terror into us, a child's joy makes us smile, and a picture of a satisfied human needs fill us with peace? Do we want to resign from it all? Unfortunately, at no point did Pico attempt to resolve such questions.

\section{Bibliography}

Aristotle, De Anima. Books II and III (with passages from Book I), transl. with Introduction and Notes by D. W. Hamlyn, with a Report on Recent Work and a Revised Bibliography by Ch. Shields, New York: Oxford University Press, 2002.

Garin E. Filozofia odrodzenia we Włoszech, transl. by K. Żaboklicki, Warszawa: PWN, 1969

Garin E. Powrót filozofów starożytnych, transl. by A. Dutka, In L. Szczucki (ed.), Renesans i reformacja. Studia z historii filozofii i idei, Warszawa: PAN IFiS, 1993, vol. 2.

25 Pico della Mirandola Gianfrancesco, On the Imagination, p. $45 \mathrm{ff}$. 
Kieszkowski B. Giovanni Pico della Mirandola, In "Przegląd filozoficzny", 1930, 33/1-4.

Pico della Mirandola Gianfrancesco. On the Imagination. The Latin Text with an Introduction, an English Translation, and Notes by Harry Caplan, Cornell Studies in English, XVI (1930).

Richards, G. B. Gianfrancesco Pico della Mirandola, Cornel University Library, typewritten, press no. T 1915 R 515.

Schmitt C. B. Gianfrancesco Pico. Leben und Werk. In Pico della Mirandola Gianfrancesco, Über die Vorstellung $=$ De Imaginatione. Lateinischdeutsche Ausgabe; mit einer Einleitung von Charles B. Schmitt, Katherine Park; herausgegeben von Eckhard Kessler, München: Fink, 1997.

Schmitt Ch. B. Gianfrancesco Pico della Mirandola (1469-1533) and His Critique of Aristotle, The Hague: M. Nijhoff, 1967.

Starobinski J. Wskazówki do historii pojęcia wyobraźni, in: „Pamiętnik Literacki", transl. by W. Kwiatkowski, LXIII, 1972/4.

Szumowski W. Historia medycyny, Warszawa: Państwowy Zakład Wydawnictw Lekarskich, 1961.

Wawrzonkowski K. Remarks on Imagination. Notes on the Margin of De Imaginatione by Gianfrancesco Pico della Mirandola (1469-1533), In Вісник НАУ. Серія: Філособія. Культурологія. 2014. № 2 (20).

\section{Summary}

The aim of the following article is to reconstruct the sources of Gianfrancesco Pico della Mirandola's (1469-1533) concept of imagination. Aristotle's views presented in De Anima are their core. However, in order to present the full picture of the concept, I also refer to Poetics. At the same time I try to show some connection between the philosophical problems undertaken by Pico and his private life. My claim is that it was his need of understanding the surrounding world, including the actions of his closest family, which made him search for a philosophical tool that would help him in that respect. He found what he was looking for in the Stagirite's views, which he attempted to supplement with the treads of Christian thought. Armed in such a way he wanted to change his own life as well as that of his family.

\section{Keywords}

Imagination, Pico, Aristotle 